DOI: 10.32844/2222-5374-2020-104-2.26

УДК: 342.124(477)

Лунін Д. С.,

здобувач Відкритого міжнародного університету розвитку

людини «Україна»

\title{
АДМІНІСТРАТИВНО-ПРАВОВИЙ СТАТУС МІНІСТЕРСТВА ЦИФРОВОЇ ТРАНСФОРМАЦІЇ УКРАЇНИ
}

Актуальність статті полягає в тому, що інформаційні процеси в сучасному суспільстві спонукають центральні органи виконавчої влади до актуалізації власної діяльності. Суспільний запит на цифровізацію, відкритість національних електронних ресурсів, упровадження електронних послуг є ключовими каталізатором реформування державної цифрової політики. Створення Міністерства цифрової трансформації України 2 вересня 2019 року стало одним із важливих кроків держави у цифровізації українського суспільства, яка є неможливою без відповідної державної політики.

Сучасні виклики, що постають у сфері цифровізації є багатовекторними. Вони пов'язані не лише з рівнем надання електронних послуг, а й $з$ проблемами цифрової грамотності громадян, інформаційною безпекою суспільства. Тому визначення адміністративно-правового статусу Міністерства цифрової трансформації України вимагає як аналізу нормативно-правових актів, так і вивчення практичної діяльності органу виконавчої влади.

Метою статті є з'ясування особливостей елементів адміністративно-правового статусу Міністерства цифрової трансформації України, їх класифікація та структурування.

Статтю присвячено теоретичному дослідженню особливостей адміністративно-правового статусу Міністерства цифрової трансформації України. Обгрунтовано здійснення державного управління у сфері електронного урядування Міністерство цифрової трансформації України, яке має визначені та чітко окреслені цілі, завдання та повноваження. Представлено авторське бачення систематизації цілей, завдань і повноважень Міністерства цифрової трансформації України як основи його адміністративно-правового статусу. Запропоновано характеристику цілей міністерства як чітко змодельованих, міжгалузевих, конкретних і спрямованих на здійснення реальних кроків. Систематизовано завдання міністерства за ключовими напрями як: завдання державного управління; завдання громадського сервісу; завдання стимулювання підприємництва. Класифіковано його повноваження за «типом повноважень» на: загальнодержавні та регіональні, адміністративні, соціальні, господарські (підприємнищькі).

Ключові слова: Міністерство цифрової трансформації України, адміністративно-правовий статус, електронне урядування, завдання, повноваження, цілі, цифровізація. 
Актуальність теми. Інформаційні процеси в сучасному суспільстві спонукають центральні органи виконавчої влади до актуалізації власної діяльності. Суспільний запит на цифровізацію, відкритість національних електронних ресурсів, упровадження електронних послуг є ключовими каталізатором реформування державної цифрової політики. Створення Міністерства цифрової трансформації України 2 вересня 2019 року стало одним із важливих кроків держави у цифровізації українського суспільства, яка $\epsilon$ неможливою без відповідної державної політики.

Сучасні виклики, що постають у сфері цифровізації $є$ багатовекторними. Вони пов'язані не лише з рівнем надання електронних послуг, а й з проблемами цифрової грамотності громадян, інформаційною безпекою суспільства. Тому визначення адміністративно-правового статусу Міністерства цифрової трансформації України вимагає як аналізу нормативно-правових актів, так і вивчення практичної діяльності органу виконавчої влади.

Аналіз попередніх досліджень і публікацій. Не зважаючи на велику кількість досліджень, що стосуються адміністративно-правового статусу органів виконавчої влади, нині $€$ підстави констатувати відсутність узагальнювальних досліджень адміністративно-правового статусу Міністерства цифрової трансформації України та порівняно невелику кількість досліджень у галузі електронного урядування. Науково-теоретичним підгрунтям окресленого питання стали праці таких дослідників: В. Авер'янов [1], В. Галунько [2], Д. Денисюк [3], О. Комісаров [5], I. Космідайло [6], I. Микульця [7], Г. Саміло [12], О. Харенко [13], О. Хлопчик [14], Ю. Шемшученко [16] та ін. Важливим $\epsilon$ аналіз діючих нормативно-правових актів, зокрема: «Положення про Міністерство цифрової трансформації України», затвердженого постановою Кабінету Міністрів України від 18 вересня 2019 р. № 856 «Питання Міністерства цифрової трансформації» [9], Плану роботи Міністерства цифрової трансформації на 2020 рік (із відповідними змінами) [10], Структури апарату Міністерства цифрової трансформації України [11].

Метою статті $є$ 3'ясування особливостей елементів адміністративно-правового статусу Міністерства цифрової трансформації України, їх класифікація та структурування.

Міністерство цифрової трансформації України є головним органом у системі центральних органів виконавчої влади, що забезпечує формування та реалізацію державної політики: у сферах цифровізації, цифрового розвитку, цифрової економіки, цифрових інновацій, електронного урядування та електронної демократії, розвитку інформаційного суспільства, інформатизації; у сфері розвитку цифрових навичок та цифрових прав громадян; у сферах відкритих даних, розвитку національних електронних інформаційних ресурсів та інтероперабельності, розвитку інфраструктури широкосмугового доступу до Інтернету та телекомунікацій, електронної комерції та бізнесу; у сфері надання електронних та адміністративних послуг; у сферах електронних довірчих послуг та електронної ідентифікації; у сфері розвитку ІТ-індустрії [9].

Серед сучасних дослідників немає єдиного визначення адміністративно-правового статусу органу виконавчої влади В. Авер'янов виокремлює три основні блоки адміністративно-правового статусу: цільовий, струк- 
турно-організаційний та компетенційний [1]. Р. Щокін пропонує розглядати адміністративно-правовий статус органу виконавчої влади як правове положення в системі суспільно-правових відносин у відповідній сфері, що визначається шляхом закріплення в нормах адміністративного права його завдань, функцій, компетенції, предметів відання, гарантій діяльності та відповідальності [17].

Аналіз нормативно-правових актів, що визначають адміністративно-правовий статус Міністерства цифрової трансформації України, дає підстави систематизувати його за трьома складниками: цілі, завдання та повноваження.

Отже, визначення цілей, завдань і повноважень Міністерства цифрової трансформації України є основою характеристики особливостей його діяльності та адміністративно-правового статусу в системі органів виконавчої влади. Якість та ефективність виконання міністерством своїх функцій безпосередньо пов'язане з чітким нормативно-правовим визначенням цілей, завдань і повноважень як ключового елементу адміністративно-правового статусу органу державної влади.

Підкреслимо, що у вітчизняних і зарубіжних наукових колах немає єдиної позиції щодо визначення категорій «цілі», «завдання», «повноваження». Тому в дослідженні важливе місце відводимо вивченню та характеристиці цих категорій.

«Цілі» є чи не найменш дослідженою категорією. Аналіз праць показав, що поширеним є ототожнення цілей із завданнями або метою. Проте 0. Комісаров визначає цілі як досяжні або можливі до виконання завдання. Відповідно до цього цілі, на його переконання, $є$ конкретнішими та чіткішими, ніж завдання. Хоча дослідник наголошує, що завдання не можуть бути нівельованими, навіть якщо цілі сформульовані. Він окреслює завдання як ціль, якої ніколи не можна досягти, але й до якої треба постійно наближатися, що отримала назву - ідеал [5, с. 90]. О. Комісаров підкреслює, що цілі можуть бути недосяжними на конкретний (запланований) момент, але наближення до них за цей час повинно відбуватися постійно [5, с. 90].

Вітчизняна дослідниця права О. Хлопчик (Степаненко) пов'язує ціль із результатами діяльності суспільства та держави, які досягаються за допомогою права як інструменту охорони і регулювання суспільних відносин $[14$, с. 91]. Паралельно з цим, на основі аналізу інших досліджень вона підкреслює, що «правова ціль» $є$ передбачуваною та ґарантованою державою моделлю соціальних станів та процесів, до якого своєю діяльністю прагнуть суб'єкти правотворчості [14, с. 91].

Міністерством цифрової трансформації України сформульовано цілі, які опубліковано на офіційному сайті:

- 100 \% публічних послуг доступні громадянам та бізнесу онлайн;

- 95 \% транспортної інфраструктури, населених пунктів та їхні соціальні об’єкти мають доступ до високошвидкісного інтернету;

- 6 млн українців залучені до програми розвитку цифрових навичок;

- 10 \% доля ІТ у ВВП країни [8].

Як бачимо, сформульовані цілі міністерства відповідають теоретичному визначенню цілей, запропонованому О. Хлопчик. Вони мають риси спроєктованої ідеальної моделі, є міжгалузевими, але й водночас конкрет- 
ними та спрямованими на здійснення реальних кроків, які піддаються аналізу без спеціального глибокого моніторингу. Важливо, що результат досягнення цілей спрямований на громадянина України та рівень цифрового сервісу, яким він може скористатися. Важливо, що окремо визначено як ціль і 10\% долю ІТ у ВВП країна. Вона є, безумовно, амбітною, але й важливою в контексті не тільки статичних досягнень цифровізації на певному етапі, а й спрямованості на розвиток суспільства, економіки та державотворчих процесів.

Наступною категорією нашого дослідження $\epsilon$ «завдання». 3 точки зору соціофілософії «завдання» розглядається як необхідність для суб’єкта (суспільства, соціальної спільноти, особи) здійснити у майбутньому визначену діяльність результатом, якої є досягнення мети [7, с. 51 ; 3, с. 100]. Відзначимо, що в даному випадку мета розглядається як ідеальний, визначений результат людської діяльності, спрямований на перетворення дійсності відповідно до усвідомленої людиною потреби. Мета $є$ безпосереднім внутрішнім спонукальним мотивом до виконання завдання $[7$, с. $51 ; 3$, c. 100].

Отже, із соціофілософської точки зору завдання формулюють на основі сформованої мети та тлумачать як об'єктивну необхідність суб’єкта до певного виду діяльності.

Узагальнення категорії «завдання» проводила дослідниця юриспруденції Т. Білобров, яка пропонувала його тлумачення в кількох узагальнених тезах: 1) наперед визначений, запланований для виконання обсяг роботи, справа; 2) настанова, розпорядження виконати певне доручення; 3) мета, якої прагнуть досягти; 4) те, що хочуть здійснити [4, с. 74-75]. Відзначимо, що дослідниця негативно трактує ототожнення понять «мета» $\mathrm{i}$ «завдання», відмежовуючи їх. Вона пояснює, що таке ототожнення не дає повною мірою розкрити сутність і значення окреслених категорій [4, с. 74]. Як доказ, приводяться аргументи дослідника В. Авер'янова: «відмінність між зазначеними поняттями полягає у ступені узагальнення результатів, що мають бути досягнуті в процесі управлінської діяльності - в цілях відтворюються триваліші та значущі, ніж у завданнях показники» [1, с. 260].

Загальнотеоретичне розуміння поняття «завдання» тлумачиться як питання, що потребує вирішення на підставі певних знань та роздумів [13, c. 328].

Дослідники теорії права визначають категорію «завдання», конкретизуючи її здійсненність [5, с. 90]. Ключовим стає бачення їх реалізації суб'єктом діяльності та конкретність сформованості мети.

Отже, маємо підстави стверджувати, що завдання є своєрідним окресленням шляхів досягнення конкретної мети. Механізм досягнення бажаного результату проєктується у чітко визначених завданнях. Важливим у цьому проєктуванні $є$ передбачення конкретного результату та його наслідків для суспільства. Тому для того, щоб завдання мали сенс, вони повинні бути досяжними, але в той же час вимагають докладання належних зусиль та залучення відповідних ресурсів. Завдання повинні бути зорієнтовані як на сьогодення, так і на майбутнє, оскільки вони задають орієнтири планованого періоду, а також пропонують стандарти, за якими в кінці певного періоду оцінюватимуться результати [4, с. 76]. 
Аналізуючи завдання Міністерства цифрової трансформації України, звернемося до чинної нормативно-правової бази.

Так, у Положенні про Міністерство цифрової трансформації України завдання окреслені як формування та реалізація державної політики:

- у сферах цифровізації, цифрового розвитку, цифрової економіки, цифрових інновацій, електронного урядування та електронної демократії, розвитку інформаційного суспільства;

- у сфері розвитку цифрових навичок та цифрових прав громадян;

- у сферах відкритих даних, розвитку національних електронних інформаційних ресурсів та інтероперабельності, розвитку інфраструктури широкосмугового доступу до Інтернету та телекомунікацій, електронної комерції та бізнесу;

- у сфері надання електронних та адміністративних послуг;

- у сферах електронних довірчих послуг та електронної ідентифікації;

- у сфері розвитку IT-індустрії [9].

Відповідні визначення завдань Міністерства цифрової трансформації України йдуть дещо в розріз із попередніми теоретичними напрацюваннями, адже вони сформульовані як стимули до дій у конкретних суспільних сферах. Таке формулювання завдань гармонічно перекликається з визначенням «трансформації», а відтак є цілком логічним для досліджуваного міністерства.

Оскільки сфера цифровізації стрімко розвивається, то й завдання сформовані у динамічному ключі. Кожне з них прив'язане до певних важливих сфер життя суспільства.

Спробуємо узагальнити завдання за авторськими критеріями:

1) завдання державного управління - розвиток цифрової економіки, цифрового урядування;

2) завдання громадського сервісу - розвиток цифрових навичок та цифрових прав громадян, електронні та адміністративні послуги, електронні довірчі послуги та електронна ідентифікація;

3) завдання стимулювання підприємництва - розвиток електронної комерції та бізнесу, розвиток IT-індустрії.

Маємо всі підстави стверджувати, що завдання Міністерства цифрової трансформації України є формально визначеними та спрямованими на довгострокове виконання в рамках діяльності міністерства. Водночас діяльнісний аспект зазначеного питання безпосередньо пов'язаний із виконанням покладених на міністерство функцій.

Положенням про Міністерство цифрової трансформації України чітко окреслені повноваження міністерства, які безпосередньо витікають із сформульованих завдань. Але перед аналізом безпосередньо повноважень досліджуваного міністерства, варто дослідити теоретико-правові погляди на них та способи їх класифікації.

Ю. Шемшученко визначає повноваження як сукупність прав і обов'язків державних органів і громадських організацій, а також посадових та інших осіб, закріплених за ними у встановленому законодавством порядку для здійснення покладених на них функцій. Обсяг повноважень конкретних державних органів та їх посадових осіб залежить від їх місця в ієрархічній структурі відповідних органів. За своїм характером повноваження 
державних органів розрізняються залежно від того, до якої гілки влади належить той чи інший орган - законодавчої, виконавчої, судової. Окремо виділяються повноваження контрольно-наглядових органів (прокуратури, державних інспекцій тощо). Основними формами реалізації повноважень державними органами є прийняття ними нормативно-правових актів (законів, указів, постанов, розпоряджень, наказів тощо), а посадовими особами - здійснення організаційно-розпорядчих дій. Крім державних органів, громадських організацій і посадових осіб, певними повноваженнями можуть наділятися й окремі громадяни (наприклад, особа, уповноважена укладати цивільні угоди від імені іншої особи) [16].

Г. Саміло підкреслює, що державновладні повноваження представників апарату управління та примусу грунтуються на можливості видавати загальнообов'язкові правила поведінки - норми права [12, с. 39]. Щоправда, дослідник наголошує, що: «влада здійснюється від імені народу, який делегує владні повноваження своїм представникам» [12, с. 80].

Шукаючи критерії класифікації повноважень, доцільною буде звернутись до аналогії державними послугами. І. Космідайло розглядає різні критерії їх класифікацій за ознаками, зокрема: а) за рівнем встановлення повноважень щодо надання адміністративних послуг та правового регулювання процедури їх надання; б) за рівнем послуги; в) за типом послуги; г) за рівнем органу управління; д) за вмістом адміністративної діяльності щодо надання адміністративної послуги; е) за предметом питань, за вирішенням яких звертаються особи; є) за видами послуг; ж) за критеріями платності; з) за джерелами фінансування надання послуг; и) за категоріями одержувачів [5].

За класифікаційною ознакою «тип послуги», послуги розподіляються на загальнодержавні, адміністративні, регіональні, соціальні, господарські (підприємницькі). Адміністративні послуги, у свою чергу, розподіляються на обов'язкові та індивідуальні [там само].

Відповідно й ми, класифікуючи повноваження Міністерства цифрової трансформації України, маємо підстави вивести критерій «тип повноваження» та класифікувати представлені в Положенні повноваження на загальнодержавні, адміністративні, регіональні, соціальні, господарські (підприємницькі).

Загальнодержавні:

1) узагальнює практику застосування законодавства з питань, що належать до його компетенції, розробляє пропозиції щодо вдосконалення законодавчих актів, актів Президента України, Кабінету Міністрів України та в установленому порядку вносить їх Кабінетові Міністрів України;

2) розробляє проєкти законів та інших нормативно-правових актів із питань, що належать до його компетенції;

3) здійснює заходи щодо створення та забезпечення функціонування:

системи електронної взаємодії державних електронних інформаційних ресурсів;

- системи електронної взаємодії органів виконавчої влади;

- інтегрованої системи електронної ідентифікації;

- єдиного вебпорталу електронного урядування;

- єдиного державного вебпорталу відкритих даних;

- національного реєстру електронних інформаційних ресурсів; 
- єдиного державного вебпорталу електронних послуг;

4) розробляє пропозиції щодо:

- визначення цілей і завдань державної інформаційної політики, інтелектуальної власності та шляхів ії̈ реалізації;

- встановлення стандартів, норм, правил, порядків, класифікаторів у сферах, що належить до його компетенції;

- визначення порядку функціонування офіційних вебсайтів органів виконавчої влади, державних інформаційно-аналітичних систем, державних інформаційних ресурсів, електронних реєстрів та баз даних;

- прийняття або внесення змін до нормативно-правових актів із питань захисту персональних даних, охорони інтелектуальної власності;

5) бере участь у:

- формуванні державної політики у сферах криптографічного та технічного захисту інформації, кіберзахисту, телекомунікацій, користування радіочастотним ресурсом України, поштового зв'язку спеціального призначення, урядового фельд'єгерського зв'язку, захисту державних інформаційних ресурсів та інформації, вимога щодо захисту якої встановлена законом, в інформаційних, телекомунікаційних та інформаційно-телекомунікаційних системах і на об’єктах інформаційної діяльності, а також у сферах використання державних інформаційних ресурсів в частині захисту інформації, протидії технічним розвідкам, функціонування, безпеки та розвитку державної системи урядового зв'язку, Національної системи конфіденційного зв'язку;

- впровадженні концепції смарт-сіті органами місцевого самоврядування;

- забезпеченні розвитку віртуальних активів, блокчейну та токенізації, штучного інтелекту;

- розробленні норм, стандартів у сферах електронних довірчих послуг та електронної ідентифікації;

- розробленні критеріїв і порядку проведення оцінки стану захищеності державних інформаційних ресурсів в інформаційно-телекомунікаційних системах; організації та проведенні оцінки стану захищеності державних інформаційних ресурсів, наданні відповідних рекомендацій;

- формуванні і реалізації державної тарифної політики та політики публічних закупівель у сферах телекомунікацій, користування радіочастотним ресурсом України;

- розробленні пропозицій щодо державної політики з питань державного регулювання у сферах телекомунікацій, користування радіочастотним ресурсом, надання послуг поштового зв'язку;

- розробленні та впровадженні вимог: до форматів даних електронного документообігу в державних органах; щодо функціонування електронного документообігу; до оформлення документів, організації документообігу, зокрема електронного документообігу;

- розробленні та організації виконання державних програм із питань захисту інформації та кіберзахисту;

- здійсненні заходів щодо забезпечення функціонування Національної системи конфіденційного зв'язку та Національної телекомунікаційної мережі; 
6) здійснює управління об’єктами державної власності, що належать до сфери управління Мінцифри;

7) здійснює міжнародне співробітництво, забезпечує виконання зобов'язань, взятих за міжнародними договорами України, з питань, що належать до компетенції Мінцифри [9].

Адміністративні:

1) розробляє нормативно-технічну документацію щодо цифрових трансформацій;

2) виконує функції генерального державного замовника Національної програми інформатизації та інших державних програм цифровізації, зокрема:

- здійснює моніторинг у сфері інформатизації;

- погоджує та координує галузеві, регіональні програми та проєкти інформатизації, програми та проєкти інформатизації органів місцевого самоврядування і вносить подання Кабінетові Міністрів України щодо зупинення виконання таких програм і проєктів;

забезпечує:

- методологічну, нормативно-правову, інформаційну та організаційну підтримку процесів формування і виконання Національної програми інформатизації;

- проведення експертизи Національної програми інформатизації та окремих її завдань (проєктів);

3) проводить цифрову експертизу та готує відповідні висновки до проєктів відповідних актів Кабінету Міністрів України, міністерств та інших органів виконавчої влади;

4) проводить погодження в порядку, встановленому законодавством, призначення керівника з питань цифрового розвитку, цифрових трансформацій або цифровізації органу виконавчої влади (CDTO);

5) розробляє пропозиції щодо визначення основних напрямів розвитку системи надання електронних та адміністративних послуг, здійснює заходи з її реформування;

6) формує та веде Реєстр адміністративних послуг;

7) координує діяльність органів, що утворили центри надання адміністративних послуг із питань підвищення рівня якості надання електронних та адміністративних послуг, розвитку електронної інформаційної взаємодії таких центрів із суб'єктами надання адміністративних послуг, розширення функцій центрів і переліку послуг, які надаються через них;

8) здійснює моніторинг якості надання електронних та адміністративних послуг, широкосмугового доступу до Інтернету, відкритих даних;

9) координує діяльність міністерств, інших центральних органів виконавчої влади, Ради міністрів Автономної Республіки Крим, місцевих держадміністрацій, а також державних підприємств, установ, організацій та державних господарських об'єднань, навчальних закладів із питань, що належать до компетенції Мінцифри, надає їм необхідну методичну допомогу;

10) організовує та координує діяльність органів виконавчої влади, пов'язану із співпрацею з програмою ЄС “Єдиний цифровий ринок” (Digital Single Market), інших міжнародних програм цифрового співробітництва; 
11) здійснює моніторинг даних про вчинення та/або спроби вчинення несанкціонованих дій щодо державних інформаційних ресурсів в інформаційно-телекомунікаційних системах, а також про їх наслідки, інформує правоохоронні органи для вжиття заходів із запобігання та припинення злочинів у зазначеній сфері;

12) координує адміністрування, функціонування та використання адресного простору українського сегмента Інтернету;

13) здійснює визначені законом повноваження у сферах електронних довірчих послуг та електронної ідентифікації:

- надає адміністративну послугу шляхом внесення юридичних осіб та фізичних осіб - підприємців, які мають намір надавати електронні довірчі послуги, до Довірчого списку;

- погоджує розроблені надавачами електронних довірчих послуг порядки синхронізації часу із Всесвітнім координованим часом (UTC);

- погоджує плани припинення діяльності кваліфікованих надавачів електронних довірчих послуг;

- приймає та зберігає документовану інформацію, сформовані сертифікати (У т. ч. посилені, кваліфіковані) відкритих ключів, реєстри чинних, блокованих та скасованих сертифікатів відкритих ключів у разі припинення діяльності кваліфікованого надавача електронних довірчих послуг;

- розглядає пропозиції (зауваження) суб'єктів відносин у сфері електронних довірчих послуг щодо удосконалення державного регулювання сфери електронних довірчих послуг;

- надає суб'єктам відносин у сфері електронних довірчих послуг консультації з питань, пов'язаних із наданням електронних довірчих послуг;

- інформує відповідно до Закону України “Про електронні довірчі послуги” про обставини, які перешкоджають діяльності центрального засвідчуваного органу;

- проводить оцінку стану розвитку сфери електронних довірчих послуг за результатами проведення аналізу інформації про діяльність постачальників електронних довірчих послуг та засвідчуваного центру;

- забезпечує взаємне визнання українських та іноземних сертифікатів відкритих ключів та електронних підписів, що використовуються під час надання юридично значущих електронних послуг;

- здійснює інші повноваження у сферах електронних довірчих послуг та електронної ідентифікації, визначені законом;

14) затверджує:

- методику визначення належності бюджетних програм до сфери інформатизації;

- методику формування індикаторів розвитку інформаційного суспільства;

- порядок оброблення інформації в інтегрованій системі електронної ідентифікації, інтеграції інформаційно-телекомунікаційних систем до цієї системи, регламент роботи інтегрованої системи електронної ідентифікації та примірний договір про приєднання до цієї системи;

- примірний договір про інформаційну взаємодію та примірну угоду про підключення до системи електронної взаємодії державних електронних інформаційних ресурсів; 
- формати електронних повідомлень та обміну даними системи електронної взаємодії державних електронних інформаційних ресурсів;

- вимоги до засобів електронної ідентифікації, рівнів довіри до засобів електронної ідентифікації для їх використання у сфері електронного урядування;

15) організовує навчання державних службовців з питань, що належать до компетенції Мінцифри;

16) організовує навчання та готує пропозиції щодо вдосконалення системи розвитку цифрових навичок громадян, підготовки та перепідготовки фахівців з питань, що належать до компетенції Мінцифри [9].

Регіональні:

1) сприяє впровадженню у державних органах та органах місцевого самоврядування технологій цифрових трансформацій [9].

Соціальні:

1) здійснює розгляд звернень громадян з питань, пов’язаних з діяльністю Мінцифри, підприємств, установ та організацій, що належать до сфери його управління, а також стосовно актів, які видаються Мінцифри [9].

Господарські (підприємницькі):

1) сприяє залученню інвестицій, упровадженню новітніх технологій та використанню управлінського досвіду з питань, що належать до компетенції Мінцифри [9].

Як бачимо, узагальнення та систематизація повноважень Міністерства цифрової трансформації України показала, що ключовий акцент у діяльності органу виконавчої влади спрямований на реалізацію загальнодержавних та адміністративних повноважень. Вони $є$ найглибше формально визначені та розтлумачені. Водночас соціальні та господарські, хоч і займають значно меншу питому вагу в описовості та сформульовані цілком конкретно й логічно. Вони сформульовані на основі двох попередніх і фактично $є$ їх логічним продовженням та реалізацією в сфері суспільних відносин та підприємництва.

Підсумовуючи систематизацію та аналіз цілей, завдань та повноважень Міністерства цифрової трансформації України зазначимо, що вони $€$ основою окреслення особливостей його діяльності та адміністративно-правового статусу. Нами було схарактеризовано цілі як чітко змодельовані, міжгалузеві, конкретні та спрямовані на здійснення реальних кроків. Завдання міністерства систематизовано за ключовими напрямами: завдання державного управління; завдання громадського сервісу; завдання стимулювання підприємництва. Повноваження були класифіковані за «типом повноважень», а саме: за формою: загальнодержавні та регіональні, за напрямом: адміністративні, соціальні, господарські (підприємницькі) тощо.

У подальшому бачимо перспективи більш глибокого дослідження окремих елементів адміністративно-правового статусу Міністерства цифрової трансформації України в умовах розвитку його нормативно-правого забезпечення. 


\section{СПИСОК ВИКОРИСТАНИХ ДЖЕРЕЛ}

1. Адміністративне право України. Академічний курс : підручник / [голова ред. кол. В.Б. Авер'янов]. Київ : Юридична думка, 2004. Т. 1. Загальна частина. 584 с.

2. Адміністративне право України. Повний курс : підручник / В. Галунько, П. Діхтієвський, О. Кузьменко та ін.; за ред. В. Галунька, О. Правоторової. Видання третє. Херсон : ОЛДІ-ПЛЮС, 2020.584 с.

3. Денисюк Д. Завдання Національної поліції України: проблеми законодавчого закріплення. Підприємництво, господарства і право. 2016. № 8. C. 100-104.

4. Білобров Т. Адміністративно-правовий статус Департаменту кіберполіції Національної поліції України : дис. ... канд. юрид. наук : 12.00.07. Київ, 2020. 209 с.

5. Комісаров О. Процес цілепокладання в організації діяльності органів внутрішніх справ України на сучасному етапі розвитку : дис. ... канд. юрид. наук: 12.00.07. Запоріжжя, 2002. 237 с.

6. Космідайло I. Державні послуги: місце в системі державного управління та їх класифікація. Ефективна економіка. 2012. № 7.

7. Микульця I. Адміністративно-правовий статус органів юстиції України : дис. ... канд. юрид. наук : 12.00.07. Херсон, 2014. 203 с.

8. Міністерство цифрової трансформації України (Україна) : web-сайт. URL: https://thedigital.gov.ua.

9. Положення про Міністерство цифрової трансформації України. Постанова Кабінету Міністрів України. URL: https://www.kmu.gov.ua/npas/ pitannya-ministerstva-cifrovoyi-t180919.

10. План роботи Міністерства цифрової трансформації на 2020 рік (зі змінами). URL: https://thedigital.gov.ua/storage/uploads/files/page/ministry /\%D0\%9F\%D0\%BB\%D0\%B0\%D0\%BD_\%D0\%9C\%D1\%96\%D0\%BD\%D1\%8 6\%D0\%B8\%D1\%84\%D1\%80\%D0\%B8_2020.pdf.

11. Структура апарату Міністерства цифрової трансформації України. URL: https://thedigital.gov.ua/storage/uploads/files/page/ministry/\%D0\%BB \%D0\%B8\%D0\%BF\%D0\%B5\%D0\%BD\%D1\%8C_2020.pdf.

12. Саміло Г. Теорія держави і права : навч. посіб. Запоріжжя : Просвіта, 2010. 348 c.

13. Харенко О. Адміністративно-правовий статус центрального органу виконавчої влади: проблема змісту. Актуальні проблеми держави і права. 2011. Вип. 60. С. 325-330.

14. Хлопчик О. Категорії «ціль» та «доцільність»у кримінальному праві України. Науковий вісник Міжнародного гуманітарного університету. Серія : Юриспруденція. 2014. Вип. 9-2(2). С. 91-94.

15. Цілі до 2024 року. Міністерство та комітет цифрової трансформації України. URL: https://thedigital.gov.ua/ministry.

16. Шемшученко Ю. Повноваження Юридична енциклопедія : в 6 т. / [редкол.: Ю. Шемшученко та ін.]. Київ : Укр. енцикл., 2003. Т. 5. П-С. 736 с.

17. Щокін Р. Поняття та особливості адміністративно-правового статусу Міністерства освіти і науки України. Юридичний науковий електронний журнал : електрон. наук. фах. вид. 2018. № 3. URL: http://www.lsej.org. ua/3_2018/49.pdf 


\section{Lunin}

\section{PECULARITIES OF THE ADMINISTRATIVE AND LEGAL STATUS OF THE MINISTRY OF DIGITAL TRANSFORMATION OF UKRAINE}

The relevance of the article is that information processes in modern society encourage central executive bodies to actualize their own activities. Public demand for digitalization, openness of national electronic resources, introduction of electronic services are key catalysts for reforming the state digital policy. The establishment of the Ministry of Digital Transformation of Ukraine on September 2, 2019 was one of the important steps of the state in the digitalization of Ukrainian society, which is impossible without appropriate public policy.

Modern challenges in the field of digitalization are multi-vector. They are related not only to the level of electronic services, but also to the problems of digital literacy of citizens, information security of society. Therefore, determining the administrative and legal status of the Ministry of Digital Transformation of Ukraine requires both the analysis of regulations and the study of the practical activities of the executive body. The purpose of the article is to clarify the features of the elements of the administrative and legal status of the Ministry of Digital Transformation of Ukraine, their classification and structuring.

The article is dedicated to the theoretical study of the peculiarities of the administrative and legal status of the Ministry of Digital Transformation of Ukraine. It is substantiated that the Ministry of Digital Transformation of Ukraine has defined and outlined clear goals, tasks and powers for the implementation of public administration in the field of e-government.

The modern views in jurisprudence on the concepts: "goals", "tasks", "powers" are actualized. The author's vision on systematization of goals, tasks and powers of the Ministry of Digital Transformation of Ukraine as the basis of its administrative and legal status is presented. The description of the goals of the ministry which are clearly modeled, intersectoral, concrete and aimed at real steps is offered. The tasks of the ministry are systematized in key areas such as: tasks of public administration; public service tasks; task of entrepreneurship stimulation. Its powers are classified according to the "type of powers" into: state, administrative, communal, social, economic (business). It is determined that the key emphasis in the activities of the Ministry is aimed at the implementation of state and administrative powers. They are the most deeply and formally defined and interpreted. At the same time, it is stated that social and economic powers occupy a much smaller share in their description and yet are formulated quite specifically and logically. The author identifies prospects for future research on the administrative and legal status of the Ministry of Digital Transformation of Ukraine.

Keywords: Ministry of Digital Transformation of Ukraine, administrative and legal status, e-government, tasks, powers, goals, digitization. 